
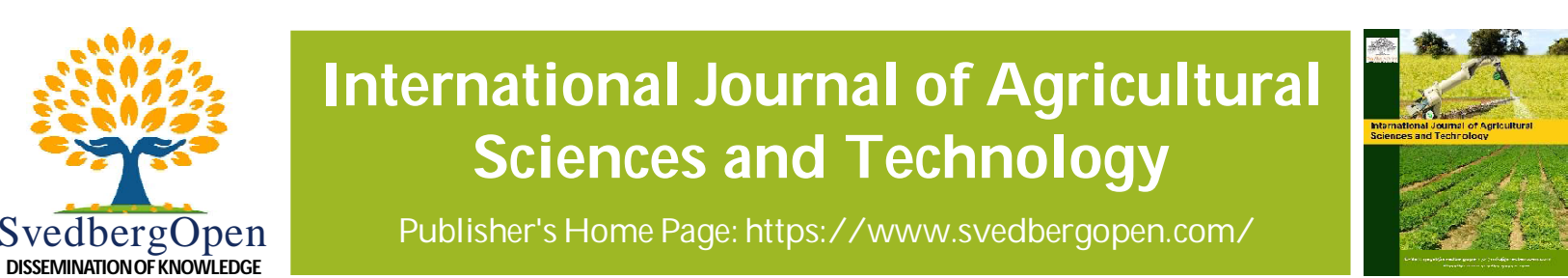

\title{
A Study on Production and Marketing of Pineapple in Kolli Hills, Namakkal District, Tamil Nadu - India
}

\author{
C. Sivakkolundu ${ }^{1 *}$
}

${ }^{1}$ Assistant Professor, Department of Economics, Thiruvalluvar University, Serkkadu, Vellore 632 115, Tamil Nadu, India. E-mail: sivakozhundu.123@gmail.com

\section{Article Info}

Volume 1, Issue 4, November 2021

Received : 09 July 2021

Accepted : 19 October 2021

Published : 05 November 2021

doi: 10.51483/IJAGST.1.4.2021.33-46

\begin{abstract}
India is the second largest producer of fruits (44 million tons) and vegetables ( 87.5 million tons) with a unique position in fruits like mango, litchi, banana, pineapple, sapota and grapes. India's share in the world production is about $10.1 \%$ in fruits and $14.4 \%$ in vegetables. The future of the Indian farmers depends on the success of the agriculture sector as India's prosperity is predominantly linked to the growth in income in the agrarian sector of the economy. India has been bestowed with wide range of climate and physio geographical conditions and as such is most suitable for growing various kinds of horticultural crops. Pineapple is the most important American fruit, and the third most important tropical fruit, after banana and mango citrus fruits being produced mainly in subtropical areas. It is cultivated in all tropical and subtropical countries. The common name for one member of and for the Bromeliaceae, a family of chiefly epiphytic herbs and small shrubs. The spiny leaves of various species of the genus Ananas yield a hard fiber called gravata in South America and pina, or pineapple cloth, in the Philippines. The fruit, whose spiny skin is yellowish brown when ripe, is sweet and juicy; it is topped by a distinctive rosette of green leaves. It is grown throughout warmer regions. The economics of pineapple production is indispensable since there is no proper farm business data on its cost of production. The accurate figure on establishment cost, operating cost and input requirement of pineapple orchard would be greatly helpful to the pineapple producers in general. This information will be of immense use to farm financing institutions. Area under pineapple is gradually expanding in the study area district. The present study is an attempt to analyze the feasibility of investment in pineapple gardens and to find out the profitability of pineapple crop.
\end{abstract}

Keywords: Pineapple Production, Agricultural Marketing, Marketing Management Concepts, Regulated Markets, Product Concept, Selling Concept

(C) 2021 C. Sivakkolundu This is an open access article under the CC BY license (https://creativecommons.org/licenses/by/4.0/), which permits unrestricted use, distribution, and reproduction in any medium, provided you give appropriate credit to the original author(s) and the source, provide a link to the Creative Commons license, and indicate if changes were made.

\section{Introduction}

The common name for one member and for the Bromeliaceae, a family of chiefly epiphytic herbs and small shrubs. The spiny leaves of various species of the genus Ananas yield a hard fiber called gravata in South America and pina, or pineapple cloth, in the Philippines. The fruit, whose spiny skin is yellowish brown when ripe, is sweet and juicy; it is

\footnotetext{
* Corresponding author: C. Sivakkolundu, Assistant Professor, Department of Economics, Thiruvalluvar University, Serkkadu, Vellore
} - 632 115. Tamil Nadu- India. E-mail: sivakozhundu.123@gmail.com 
topped by a distinctive rosette of green leaves. It is grown throughout warmer regions. Thailand, the Philippines, and Brazil are the largest producers of canned pineapple. It is known botanically as Ananas comosus Merr. The existing marketing system for the fruit in selected areas of Bogra district, Bangladesh was examined based on data from 40 market intermediaries (Begum and Raha 2002). The fruit has acquired few vernacular names. In China, it is Po-lo-mah; sometimes in Jamaica, Sweet Pine; in Guatemala often merely "Pine". In India it is successfully grown in West Bengal, Assam, Karnataka, Meghalaya, Manipur, Bihar, Goa, Tamil Nadu and Kerala. It is one of the most common fruits in India. The growers faced such as lack of road facility unawareness inadequate storage facility delayed payment and lack of market facilities (Brij Bala, 2006). Pineapple may be consumed fresh, canned, juiced, and are found in a wide array of food stuffs dessert, fruit salad, jam, yogurt, ice cream, candy, and as a complement to meat dishes (Sivakkolundu, 2012; 2013) Pineapple enzymes can interfere with the preparation of some foods, such as jelly or other gelatin-based desserts, but would be destroyed during cooking and the canning process (Sivakkolundu, 2016). The region, consisting of 18 nadus (villages) including the present Rasipuram and Senthamangalam, were under this rule (Chapke, 2000).

\section{Objectives}

- To find out the socioeconomic status of farmers in the study area.

- To study the trends in cost of pineapple cultivation.

- To analyze estimate the economics of pineapple production on the basis of benefit cost analysis in the study area.

- To find out the problems faced by the sample farmers in study area.

- To suggest some suitable policy measure to enhance the sustainability of pineapple cultivation in the study area on the basis of findings of the present study.

\section{Statement of the Problem}

In the process of marketing the producer has to incur various marketing costs. The use of chemical pesticides need to be minimized so that it would be ecologically least destructive, economically viable (Gunjate, 1997). These costs are determined by the producer's performance and efficiency of different marketing functionaries which in turn influence the returns to the growers. During marketing stage, the pineapple producers may be faced with manifold problems which have direct bearing upon the prosperity of producers. The main marketing problems are market finance, price fluctuation etc. Even if the production technology is advanced, unless marketing is improved simultaneously, efforts to increase the yield and production may go waste (Hiremath, 1993; More, 1999). The increase in production and productivity was due to the use of improved cultural practices, increased use of manures, fertilizers and plant protection chemicals (More et al., 2000).

\section{Hypotheses}

- There is significant difference in socioeconomic status of farmers in the study area.

- There is a significant inter village variation and farm size variation in cost of pineapple cultivation from the stage of growing period to the stage of production of pineapple among the selected farm households in Kollimalai, Namakkal district.

- There is significant farm wise variation with respect to economics of pineapple production on the basis of benefit cost analysis in the study area.

- The respondents differ significantly in their mode of marketing pineapple.

\section{Methodology}

This study aims at analyzing the pattern of pineapple cultivation in Kolli hills, Namakkal district. It analyses various components of cost of cultivation of pineapple on the basis of results obtained through field survey. It also examines the economics of pineapple cultivation in terms of gross or net profit of pineapple cultivation. The design of the study is analytical method.

\subsection{Sampling}

Kolli hills has about 35 revenue villages. Out of them six villages are selected as sample according to the performance of pineapple cultivation. Arasampatty village has 78 pineapple growing farmers and among them 50 are selected as sample constituting $64.10 \%$ of the universe. Keeraikadu village has 82 pineapple growing farmers and among them 50 are selected as sample constituting $60.97 \%$ of the universe. Sellipatty village has 95 pineapple growing farmers and among them 50 are selected as sample constituting $52.63 \%$ of the universe. Bellakadu village has 76 pineapple growing farmers and among them 50 are selected as sample constituting 65.78\% of the universe (Patil and Pramod Kumar, 1986). Thottikadu village has 98 pineapple growing farmers and among them 50 are selected as sample constituting $51.02 \%$ of the universe. Vadugarpatty village has 89 pineapple growing farmer and among them 50 are selected as sample constituting $56.17 \%$ of 
the universe. Thus in total 300 pineapple growing farmers are selected as sample on the basis of purposive random sampling method. The growth rates in area, production and productivity and the factor responsible for change in acreage under the crop (Pawan et al., 2002).

\section{Data Collection}

The relevant primary data are collected from the respondents by employing a well structured interview schedule. The researcher has visited each village and met the respondents. The relevant secondary data are collected from the various government reports, such as reports of District Rural Development Agency, and Director of Statistics.

\section{Data Analysis}

The collected data are classified and tabulated with the help of computer programming. Cross tabulation is made for data pertaining to socioeconomic background of the respondents.

\subsection{Limitations}

- The chances of recall bias among the respondents maybe greater, which will not give a true picture about the study area.

- There are chances for human bias and most of them do not maintain account for their expenditure on the inputs.

- Kolli Hills is a truly rugged terrain and is not meant for the faint-hearted. It takes courage to even consider and plan a trip to this virgin hill.

- Located just $100 \mathrm{kms}$ from Salem town, it is accessible yet outside the reach of unadventurous souls.

\section{Results and Discussion}

Data presented in Table 1 indicates out of 300 respondents 14.33 per of them belong to the backward caste and $23.67 \%$ of them belong to the most backward caste. It was found the schedules caste and scheduled tribes contributed $22.67 \%$ and $39.33 \%$ respectively in the total respondent. The concentration of scheduled tribes was found in the areas of Arasampatti, Bellakadu and Vadagurpatty.

Table 1: Caste Wise Distribution of Respondents

\begin{tabular}{|c|c|c|c|c|c|}
\hline Area & Backward Caste & Most Backward Caste & Schedule Caste & Schedule Tribe & Total \\
\hline Arasampatti & $\begin{array}{c}8 \\
(16.00)\end{array}$ & $\begin{array}{c}10 \\
(20.00)\end{array}$ & $\begin{array}{c}9 \\
(18.00)\end{array}$ & $\begin{array}{c}23 \\
(46.00)\end{array}$ & 50 \\
\hline Keeraikadu & $\begin{array}{c}7 \\
(14.00)\end{array}$ & $\begin{array}{c}21 \\
(42.00)\end{array}$ & $\begin{array}{c}8 \\
(16.00)\end{array}$ & $\begin{array}{c}14 \\
(28.00)\end{array}$ & 50 \\
\hline Sellipatty & $\begin{array}{c}6 \\
(12.00)\end{array}$ & $\begin{array}{c}12 \\
(24.00)\end{array}$ & $\begin{array}{c}21 \\
(42.00)\end{array}$ & $\begin{array}{c}11 \\
(22.00)\end{array}$ & 50 \\
\hline Bellakadu & $\begin{array}{c}9 \\
(18.00)\end{array}$ & $\begin{array}{c}8 \\
(16.00)\end{array}$ & $\begin{array}{c}11 \\
(22.00)\end{array}$ & $\begin{array}{c}22 \\
(44.00)\end{array}$ & 50 \\
\hline Thottikadu & $\begin{array}{c}5 \\
(10.00)\end{array}$ & $\begin{array}{c}9 \\
(18.00)\end{array}$ & $\begin{array}{c}13 \\
(26.00)\end{array}$ & $\begin{array}{c}23 \\
(46.00)\end{array}$ & 50 \\
\hline Vadagurpatty & $\begin{array}{c}8 \\
(16.00)\end{array}$ & $\begin{array}{c}11 \\
(22.00)\end{array}$ & $\begin{array}{c}6 \\
(12.00)\end{array}$ & $\begin{array}{c}25 \\
(50.00)\end{array}$ & 50 \\
\hline Total & $\begin{array}{c}43 \\
(14.33)\end{array}$ & $\begin{array}{c}71 \\
(23.67)\end{array}$ & $\begin{array}{c}68 \\
(22.67)\end{array}$ & $\begin{array}{c}118 \\
(39.33)\end{array}$ & 300 \\
\hline
\end{tabular}

The Table 2 indicates the age wise distribution of respondents. Out of 300 respondents $33 \%$ of them belong to the age group of 20-30 years, $25 \%$ of them come under the age group of 30-40 years and $20.33 \%$ of them belong to the age group of 40-50 years. Moreover $21.67 \%$ of them belong to the age group of 50-60 years. Majority of the respondents in 


\begin{tabular}{|c|c|c|c|c|c|}
\hline Area & $20-30$ & $30-40$ & $40-50$ & $50-60$ & Total \\
\hline Arasampatti & $\begin{array}{c}19 \\
(38.00)\end{array}$ & $\begin{array}{c}11 \\
(22.00)\end{array}$ & $\begin{array}{c}12 \\
(24.00)\end{array}$ & $\begin{array}{c}8 \\
(16.00)\end{array}$ & 50 \\
\hline Keeraikadu & $\begin{array}{c}15 \\
(30.00)\end{array}$ & $\begin{array}{c}13 \\
(26.00)\end{array}$ & $\begin{array}{c}12 \\
(24.00)\end{array}$ & $\begin{array}{c}10 \\
(20.00)\end{array}$ & 50 \\
\hline Sellipatty & $\begin{array}{c}19 \\
(38.00)\end{array}$ & $\begin{array}{c}9 \\
(18.00)\end{array}$ & $\begin{array}{c}10 \\
(20.00)\end{array}$ & $\begin{array}{c}12 \\
(24.00)\end{array}$ & 50 \\
\hline Bellakadu & $\begin{array}{c}20 \\
(40.00)\end{array}$ & $\begin{array}{c}15 \\
(30.00)\end{array}$ & $\begin{array}{c}7 \\
(14.00)\end{array}$ & $\begin{array}{c}8 \\
(16.00)\end{array}$ & 50 \\
\hline Thottikadu & $\begin{array}{c}18 \\
(36.00)\end{array}$ & $\begin{array}{c}12 \\
(24.00)\end{array}$ & $\begin{array}{c}11 \\
(22.00)\end{array}$ & $\begin{array}{c}9 \\
(18.00)\end{array}$ & 50 \\
\hline Vadagurpatty & $\begin{array}{c}8 \\
(16.00)\end{array}$ & $\begin{array}{c}15 \\
(30.00)\end{array}$ & $\begin{array}{c}9 \\
(18.00)\end{array}$ & $\begin{array}{c}18 \\
(36.00)\end{array}$ & 50 \\
\hline Total & $\begin{array}{c}99 \\
(33.00)\end{array}$ & $\begin{array}{c}75 \\
(25.00)\end{array}$ & $\begin{array}{c}61 \\
(20.33)\end{array}$ & $\begin{array}{c}65 \\
(21.67)\end{array}$ & 300 \\
\hline
\end{tabular}

the areas of Bellakadu village, Thottikadu village, Sellipatty village, Keeraikadu village, and Arasampatti village fall under the age group of below 40 years.

The Table 3 indicates the farm wise distribution of respondents. It is observed that out of 300 respondents, $33 \%$ of them are marginal farmers and $31.33 \%$ of them belong to the small farmers group. In this study $22.33 \%$ of them belong to the medium farm group and the rest $13.33 \%$ of them belong to the large farm group. The areas such as Arasampatti village (54.00\%), Sellipatty village (34.00\%), and Thottikadu village (32.00\%), witnessed large number of small farmers.

\begin{tabular}{|c|c|c|c|c|c|}
\hline Area & Marginal & Small & Medium & Large & Total \\
\hline Arasampatti & $\begin{array}{c}27 \\
(54.00)\end{array}$ & $\begin{array}{c}12 \\
(24.00)\end{array}$ & $\begin{array}{c}6 \\
(12.00)\end{array}$ & $\begin{array}{c}5 \\
(10.00)\end{array}$ & 50 \\
\hline Keeraikadu & $\begin{array}{c}11 \\
(22.00)\end{array}$ & $\begin{array}{c}24 \\
(48.00)\end{array}$ & $\begin{array}{c}8 \\
(16.00)\end{array}$ & $\begin{array}{c}7 \\
(14.00)\end{array}$ & 50 \\
\hline Sellipatty & $\begin{array}{c}17 \\
(34.00)\end{array}$ & $\begin{array}{c}13 \\
(26.00)\end{array}$ & $\begin{array}{c}11 \\
(22.00)\end{array}$ & $\begin{array}{c}9 \\
(18.00)\end{array}$ & 50 \\
\hline Bellakadu & $\begin{array}{c}7 \\
(14.00)\end{array}$ & $\begin{array}{c}9 \\
(18.00\end{array}$ & $\begin{array}{c}26 \\
(52.00)\end{array}$ & $\begin{array}{c}8 \\
(16.00)\end{array}$ & 50 \\
\hline Thottikadu & $\begin{array}{c}21 \\
(42.00)\end{array}$ & $\begin{array}{c}14 \\
(28.00)\end{array}$ & $\begin{array}{c}9 \\
(18.00)\end{array}$ & $\begin{array}{c}6 \\
(12.00)\end{array}$ & 50 \\
\hline Vadagurpatty & $\begin{array}{c}16 \\
(32.00)\end{array}$ & $\begin{array}{c}22 \\
(44.00)\end{array}$ & $\begin{array}{c}7 \\
(14.00)\end{array}$ & $\begin{array}{c}5 \\
(10.00)\end{array}$ & 50 \\
\hline Total & $\begin{array}{c}99 \\
(33.00)\end{array}$ & $\begin{array}{c}94 \\
(31.33)\end{array}$ & $\begin{array}{c}67 \\
(22.33)\end{array}$ & $\begin{array}{c}40 \\
(13.33)\end{array}$ & 300 \\
\hline
\end{tabular}


The Table 4 presents the education wise distribution of respondents. Among the total farmers, $30 \%$ of them completed their primary education, $25.67 \%$ of them completed pre secondary level education and $19 \%$ of them completed secondary level education. It was found that $13 \%$ of the respondents are educated up to higher secondary and the rest (12.33\%) of them are degree holders. Areas such as Arasampatti village (40.00\%), Bellakadu village (34.00\%), Thottikadu village $(32.00 \%)$, and Vadagurpatty village $(44.00 \%)$ have more numbers of respondents with primary education.

\begin{tabular}{|c|c|c|c|c|c|c|}
\hline Area & Primary & Pre Secondary & Secondary & Higher Secondary & Degree & Total \\
\hline Arasampatti & $\begin{array}{c}20 \\
(40.00)\end{array}$ & $\begin{array}{c}12 \\
(24.00)\end{array}$ & $\begin{array}{c}7 \\
(14.00)\end{array}$ & $\begin{array}{c}6 \\
(12.00)\end{array}$ & $\begin{array}{c}5 \\
(10.00)\end{array}$ & 50 \\
\hline Keeraikadu & $\begin{array}{c}7 \\
(14.00)\end{array}$ & $\begin{array}{c}21 \\
(42.00)\end{array}$ & $\begin{array}{c}9 \\
(18.00)\end{array}$ & $\begin{array}{c}7 \\
(14.00)\end{array}$ & $\begin{array}{c}6 \\
(12.00)\end{array}$ & 50 \\
\hline Sellipatty & $\begin{array}{c}8 \\
(16.00)\end{array}$ & $\begin{array}{c}11 \\
(22.00)\end{array}$ & $\begin{array}{c}16 \\
(32.00)\end{array}$ & $\begin{array}{c}8 \\
(16.00)\end{array}$ & $\begin{array}{c}7 \\
(14.00)\end{array}$ & 50 \\
\hline Bellakadu & $\begin{array}{c}17 \\
(34.00)\end{array}$ & $\begin{array}{c}12 \\
(24.00)\end{array}$ & $\begin{array}{c}9 \\
(18.00)\end{array}$ & $\begin{array}{c}7 \\
(14.00)\end{array}$ & $\begin{array}{c}5 \\
(10.00)\end{array}$ & 50 \\
\hline Thottikadu & $\begin{array}{c}16 \\
(32.00)\end{array}$ & $\begin{array}{c}13 \\
(26.00)\end{array}$ & $\begin{array}{c}7 \\
(14.00)\end{array}$ & $\begin{array}{c}6 \\
(12.00)\end{array}$ & $\begin{array}{c}8 \\
(16.00)\end{array}$ & 50 \\
\hline Vadagurpatty & $\begin{array}{c}22 \\
(44.00)\end{array}$ & $\begin{array}{c}8 \\
(16.00)\end{array}$ & $\begin{array}{c}9 \\
(18.00)\end{array}$ & $\begin{array}{c}5 \\
(10.00)\end{array}$ & $\begin{array}{c}6 \\
(12.00)\end{array}$ & 50 \\
\hline Total & $\begin{array}{c}90 \\
(30.00)\end{array}$ & $\begin{array}{c}77 \\
(25.67)\end{array}$ & $\begin{array}{c}57 \\
(19.00)\end{array}$ & $\begin{array}{c}39 \\
(13.00)\end{array}$ & $\begin{array}{c}37 \\
(12.33)\end{array}$ & 300 \\
\hline
\end{tabular}

The Table 5 reveals the income wise distribution of respondents. Out of 300 respondents, $23 \%$ of them earn monthly income below Rs. 5000, $22 \%$ of them earn monthly income in the range of Rs. 5000 to Rs. 7500 and $20.67 \%$ of them belong

\begin{tabular}{|c|c|c|c|c|c|c|}
\hline Area & Below 5000 & $5000-7500$ & $7500-10000$ & $10000-12250$ & Above 12250 & Total \\
\hline Arasampatti & $\begin{array}{c}17 \\
(34.00)\end{array}$ & $\begin{array}{c}10 \\
(20.00)\end{array}$ & $\begin{array}{c}8 \\
(16.00)\end{array}$ & $\begin{array}{c}6 \\
(12.00)\end{array}$ & $\begin{array}{c}9 \\
(18.00)\end{array}$ & 50 \\
\hline Keeraikadu & $\begin{array}{c}8 \\
(16.00)\end{array}$ & $\begin{array}{c}11 \\
(22.00)\end{array}$ & $\begin{array}{c}12 \\
(24.00)\end{array}$ & $\begin{array}{c}7 \\
(14.00)\end{array}$ & $\begin{array}{c}12 \\
(24.00)\end{array}$ & 50 \\
\hline Sellipatty & $\begin{array}{c}8 \\
(16.00)\end{array}$ & $\begin{array}{c}10 \\
(20.00)\end{array}$ & $\begin{array}{c}14 \\
(28.00)\end{array}$ & $\begin{array}{c}9 \\
(18.00)\end{array}$ & $\begin{array}{c}9 \\
(18.00)\end{array}$ & 50 \\
\hline Bellakadu & $\begin{array}{c}13 \\
(26.00)\end{array}$ & $\begin{array}{c}10 \\
(20.00)\end{array}$ & $\begin{array}{c}10 \\
(20.00)\end{array}$ & $\begin{array}{c}8 \\
(16.00)\end{array}$ & $\begin{array}{c}9 \\
(18.00)\end{array}$ & 50 \\
\hline Thottikadu & $\begin{array}{c}15 \\
(30.00)\end{array}$ & $\begin{array}{c}12 \\
(24.00)\end{array}$ & $\begin{array}{c}6 \\
(12.00)\end{array}$ & $\begin{array}{c}5 \\
(10.00)\end{array}$ & $\begin{array}{c}12 \\
(24.00)\end{array}$ & 50 \\
\hline Vadagurpatty & $\begin{array}{c}8 \\
(16.00)\end{array}$ & $\begin{array}{c}13 \\
(26.00)\end{array}$ & $\begin{array}{c}12 \\
(24.00)\end{array}$ & $\begin{array}{c}9 \\
(18.00)\end{array}$ & $\begin{array}{c}8 \\
(16.00)\end{array}$ & 50 \\
\hline Total & $\begin{array}{c}69 \\
(23.00)\end{array}$ & $\begin{array}{c}66 \\
(22.00)\end{array}$ & $\begin{array}{c}62 \\
(20.67)\end{array}$ & $\begin{array}{c}44 \\
(14.67)\end{array}$ & $\begin{array}{c}59 \\
(19.67)\end{array}$ & 300 \\
\hline
\end{tabular}


to the monthly income group which covers the range of Rs. $7500-10000$. It was found that $14.67 \%$ of them belong to the income bracket of Rs. 10000-12250 and the rest (19.67\%) belong to the monthly income group of above Rs. 12250. It is obvious that majority of the sample farmers fall under the lower income categories.

Data presented in Table 6 indicates the family size wise distribution of respondents. A considerable number of respondents of Arasampatti village (44.00\%), belong to the large family size. From this analysis it is concluded that a vast majority of the respondents fall under the categories of small and medium sized families.

Table 6: Family Size Wise Distribution of Respondents

\begin{tabular}{|c|c|c|c|c|}
\hline Area & Small & Medium & Large & Total \\
\hline Arasampatti & $\begin{array}{c}12 \\
(4.00)\end{array}$ & $\begin{array}{c}16 \\
(32.00)\end{array}$ & $\begin{array}{c}22 \\
(44.00)\end{array}$ & 50 \\
\hline Keeraikadu & $\begin{array}{c}11 \\
(22.00)\end{array}$ & $\begin{array}{c}21 \\
(42.00)\end{array}$ & $\begin{array}{c}18 \\
(36.00)\end{array}$ & 50 \\
\hline Sellipatty & $\begin{array}{c}26 \\
(52.00)\end{array}$ & $\begin{array}{c}12 \\
(24.00)\end{array}$ & $\begin{array}{c}12 \\
(24.00)\end{array}$ & 50 \\
\hline Bellakadu & $\begin{array}{c}15 \\
(30.00)\end{array}$ & $\begin{array}{c}27 \\
(54.00)\end{array}$ & $\begin{array}{c}8 \\
(16.00)\end{array}$ & 50 \\
\hline Thottikadu & $\begin{array}{c}28 \\
(56.00)\end{array}$ & $\begin{array}{c}13 \\
(26.00)\end{array}$ & $\begin{array}{c}9 \\
(18.00)\end{array}$ & 50 \\
\hline Vadagurpatty & $\begin{array}{c}23 \\
(46.00)\end{array}$ & $\begin{array}{c}16 \\
(32.00)\end{array}$ & $\begin{array}{c}11 \\
(22.00)\end{array}$ & 50 \\
\hline Total & $\begin{array}{c}115 \\
(38.33)\end{array}$ & $\begin{array}{c}105 \\
(35.00)\end{array}$ & $\begin{array}{c}80 \\
(26.67)\end{array}$ & 300 \\
\hline
\end{tabular}

Source : Primary Data

Table 7 presents the housing type wise distribution of respondents. It was observed that out of 300 respondents, $12.67 \%$ of them live in the thatched houses, $21.67 \%$ of them dwell in the tiled houses and $20.33 \%$ of them live in terraced

Table 7: Housing Type Wise Distribution of Respondents

\begin{tabular}{|c|c|c|c|c|c|c|}
\hline Area & Thatched & Tiled & Terraced & $\begin{array}{l}\text { Partly Tiled } \\
\text { and Terraced }\end{array}$ & $\begin{array}{c}\text { Partly } \\
\text { Thatched and Tiled }\end{array}$ & Total \\
\hline Arasampatti & $\begin{array}{c}20 \\
(40.00)\end{array}$ & $\begin{array}{c}7 \\
(14.00)\end{array}$ & $\begin{array}{c}8 \\
(16.00)\end{array}$ & $\begin{array}{c}9 \\
(18.00)\end{array}$ & $\begin{array}{c}6 \\
(12.00)\end{array}$ & 50 \\
\hline Keeraikadu & $\begin{array}{c}12 \\
(24.00)\end{array}$ & $\begin{array}{c}20 \\
(40.00)\end{array}$ & $\begin{array}{c}6 \\
(12.00)\end{array}$ & $\begin{array}{c}5 \\
(10.00)\end{array}$ & $\begin{array}{c}7 \\
(14.00)\end{array}$ & 50 \\
\hline Sellipatty & $\begin{array}{c}8 \\
(16.00)\end{array}$ & $\begin{array}{c}9 \\
(18.00)\end{array}$ & $\begin{array}{c}21 \\
(42.00)\end{array}$ & $\begin{array}{c}7 \\
(14.00)\end{array}$ & $\begin{array}{c}5 \\
(10.00)\end{array}$ & 50 \\
\hline Bellakadu & $\begin{array}{c}20 \\
(40.00)\end{array}$ & $\begin{array}{c}9 \\
(18.00)\end{array}$ & $\begin{array}{c}7 \\
(14.00)\end{array}$ & $\begin{array}{c}8 \\
(16.00)\end{array}$ & $\begin{array}{c}6 \\
(12.00)\end{array}$ & 50 \\
\hline Thottikadu & $\begin{array}{c}9 \\
(18.00)\end{array}$ & $\begin{array}{c}13 \\
(26.00)\end{array}$ & $\begin{array}{c}11 \\
(22.00)\end{array}$ & $\begin{array}{c}9 \\
(18.00)\end{array}$ & $\begin{array}{c}8 \\
(16.00)\end{array}$ & 50 \\
\hline Vadagurpatty & $\begin{array}{c}14 \\
(28.00)\end{array}$ & $\begin{array}{c}7 \\
(14.00)\end{array}$ & $\begin{array}{c}8 \\
(16.00)\end{array}$ & $\begin{array}{c}11 \\
(22.00)\end{array}$ & $\begin{array}{c}10 \\
(20.00)\end{array}$ & 50 \\
\hline Total & $\begin{array}{c}83 \\
(27.67)\end{array}$ & $\begin{array}{c}65 \\
(21.67)\end{array}$ & $\begin{array}{c}61 \\
(20.33)\end{array}$ & $\begin{array}{c}49 \\
(16.33)\end{array}$ & $\begin{array}{c}42 \\
(14.00)\end{array}$ & 300 \\
\hline
\end{tabular}


houses. A considerable number of respondents of Keeraikadu village (40.00\%) and Thottikadu village (26.00\%) reside in the tiled houses.

The Table 8 shows the village wise cost-benefit of pineapple cultivation. The yield of pineapple per acre was found to be $7038 \mathrm{~kg}$. This analysis exhibited that an average of pineapple production per acre was calculated to be $7038 \mathrm{~kg}$. It is observed that inter village variation is observed in income generation from pineapple cultivation. Vadagurpatty village ranks the first position in income generation from pineapple cultivation, Thottikadu village the second, Sellipatty village the third, Bellakadu village the fourth, Keeraikadu village the fifth and Arasampatty village the last.

\begin{tabular}{|c|c|c|c|c|c|}
\hline Village & $\begin{array}{l}\text { Total Cost Of } \\
\text { Production }\end{array}$ & $\begin{array}{c}\text { Yield } \\
\text { Per Acre }\end{array}$ & $\begin{array}{c}\text { Income Per } \\
\text { Acre Pineapple } \\
\text { Cultivation }\end{array}$ & $\begin{array}{l}\text { Income From } \\
\text { Inter Crop } \\
\text { Cultivation }\end{array}$ & Total Income \\
\hline Arasampatty & 104614 & 6557 & $\begin{array}{l}131140 \\
(87.92)\end{array}$ & $\begin{array}{c}18025 \\
(12.08)\end{array}$ & 149165 \\
\hline Keeraikadu & 105031 & 6819 & $\begin{array}{l}136380 \\
(87.74)\end{array}$ & $\begin{array}{c}19046 \\
(12.26)\end{array}$ & 155426 \\
\hline Sellipatty & 112900 & 6915 & $\begin{array}{l}138300 \\
(86.79)\end{array}$ & $\begin{array}{c}21035 \\
(13.21)\end{array}$ & 159335 \\
\hline Bellakadu & 119597 & 6795 & $\begin{array}{l}135900 \\
(85.02)\end{array}$ & $\begin{array}{c}22450 \\
(14.18)\end{array}$ & 158350 \\
\hline Thottikadu & 126641 & 7028 & $\begin{array}{l}140560 \\
(82.39)\end{array}$ & $\begin{array}{c}30035 \\
(17.61)\end{array}$ & 170595 \\
\hline Vadagurpatty & 131805 & 8115 & $\begin{array}{l}162300 \\
(83.45)\end{array}$ & $\begin{array}{c}32165 \\
(16.55)\end{array}$ & 194465 \\
\hline Total & 118837 & 7038 & $\begin{array}{l}140760 \\
(85.54)\end{array}$ & $\begin{array}{c}23792 \\
(14.46)\end{array}$ & 164552 \\
\hline
\end{tabular}

The Table 9 portrays the farms wise cost benefit analysis of pineapple cultivation in the study area. The marginal farmers were ranked the first position with respect to yield of pineapple as it was worked out to be $8015 \mathrm{~kg}$ per acre. The

\begin{tabular}{|l|c|c|c|c|c|}
\hline Table 9: Farm Wise Cost Benefit Analysis \\
\hline Farm & $\begin{array}{c}\text { Total Cost of } \\
\text { Production }\end{array}$ & $\begin{array}{c}\text { Yield } \\
\text { per Acre }\end{array}$ & $\begin{array}{c}\text { Income per } \\
\text { Acre Pineapple } \\
\text { Cultivation }\end{array}$ & $\begin{array}{c}\text { Income from } \\
\text { Inter Crop } \\
\text { Cultivation }\end{array}$ & Total Income \\
\hline Marginal & 105959 & $\begin{array}{c}8015 \\
(86.01)\end{array}$ & $\begin{array}{l}160300 \\
(13.99)\end{array}$ & 26165 & 186365 \\
\hline Small & 115125 & $\begin{array}{c}7632 \\
(85.61)\end{array}$ & $\begin{array}{c}152640 \\
(14.39)\end{array}$ & 25655 & 178295 \\
\hline Medium & 125700 & $\begin{array}{c}6890 \\
(81.63)\end{array}$ & $\begin{array}{c}137800 \\
(12.37)\end{array}$ & 19450 & 157250 \\
\hline Large & 132550 & $\begin{array}{c}(89.30) \\
(8038\end{array}$ & $\begin{array}{c}139700 \\
(11.70)\end{array}$ & 18500 & 158200 \\
\hline Total & 118837 & & & 23792 & 164552 \\
\hline Source : Primary Data & & & & & \\
\hline
\end{tabular}


small farmers take the second position with respect to yield of pineapple as it was worked out to be $7632 \mathrm{~kg}$ per acre. The large farmers occupy the third position with respect to yield of pineapple as it was worked out to be $6985 \mathrm{~kg}$ per acre. The medium farmers rank the fourth position with respect to yield of pineapple as it is worked out to be $6890 \mathrm{~kg}$ per acre.

It is seen clearly from the Table 10 that overall cost ratio of pineapple cultivation is worked out to be 1.38 including inter-crop cultivation and 1.18 for pineapple cultivation alone. Among the sample farmers, the performance of marginal farmers is best with respect to economics of pineapple cultivation and it is last in the case of large farmers. The cost of marketing was higher in guava than in mango and apple (Sathihal, 1993).

\begin{tabular}{|l|c|c|c|c|c|c|}
\hline \multicolumn{2}{|c|}{ Table 10: Farm Wise Cost of Pineapple Cultivation } \\
\hline Farm & $\begin{array}{c}\text { Total } \\
\text { Cost of } \\
\text { Production }\end{array}$ & $\begin{array}{c}\text { Income from } \\
\text { Pineapple } \\
\text { Cultivation }\end{array}$ & Cost Ratio & $\begin{array}{c}\text { Total } \\
\text { Cost of } \\
\text { Production }\end{array}$ & $\begin{array}{c}\text { Total Income } \\
\text { Including } \\
\text { Inter Crop }\end{array}$ & Cost Ratio \\
\hline Marginal & 105959 & 160300 & 1.51 & 105959 & 186365 & 1.75 \\
\hline Small & 115125 & 152640 & 1.32 & 115125 & 178295 & 1.54 \\
\hline Medium & 125700 & 137800 & 1.09 & 125700 & 157250 & 1.25 \\
\hline Large & 132550 & 139700 & 1.05 & 132550 & 158200 & 1.19 \\
\hline Total & 118837 & 140760 & 1.18 & 118837 & 164552 & 1.38 \\
\hline \multicolumn{7}{|l|}{ Source : Primary Data }
\end{tabular}

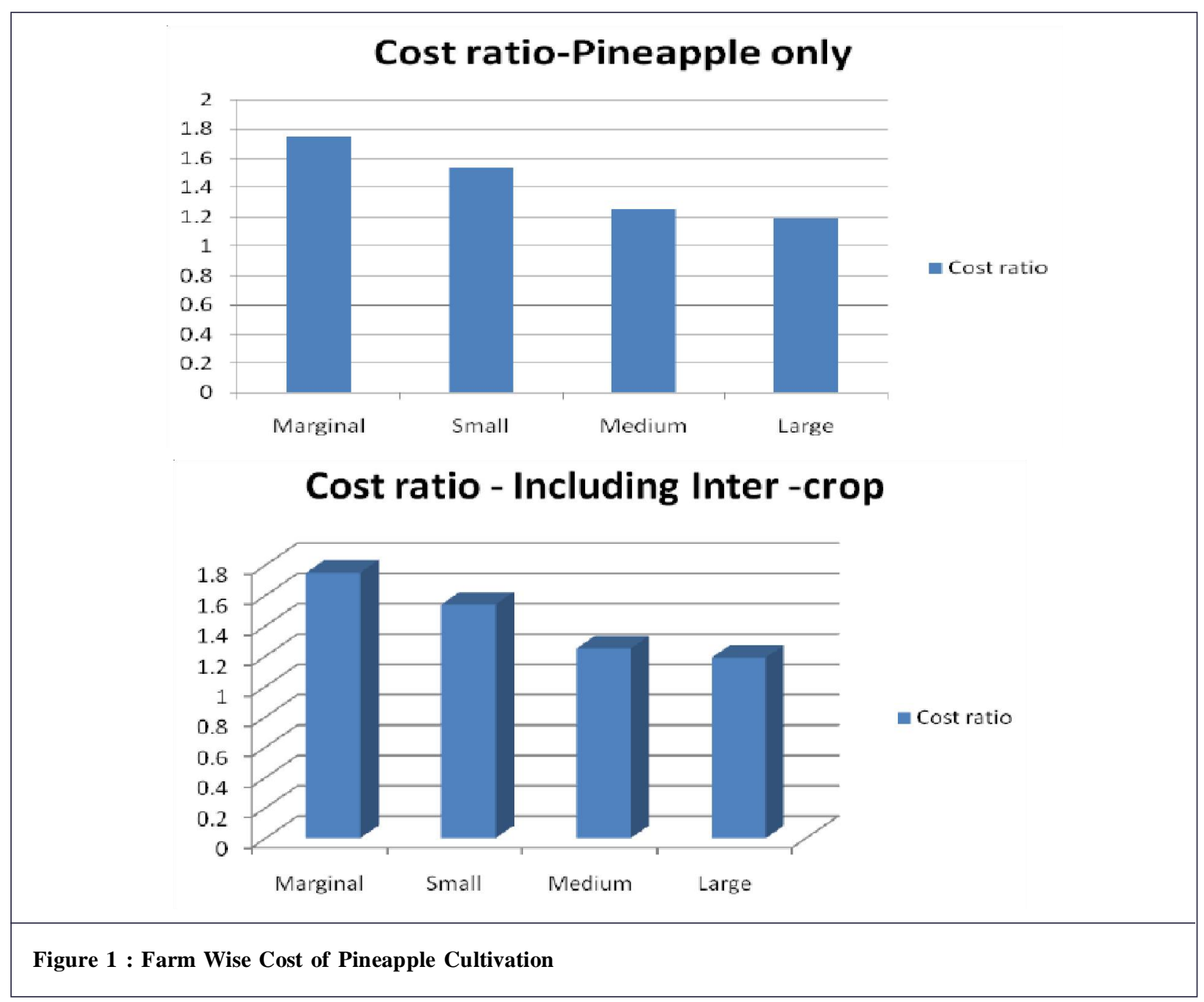


The Table 11 presents the results of multiple regression results on pineapple production in the case of large farmers. There are ten independent variables were chosen.

Among these independent variables, mechanization, caste, fertilizer used, education and pesticide level are the important independent variables which positively affect the pineapple production. The year to year fluctuations in area and production of fruit crops were examined with the help of index numbers and their percentage changes from the previous years (Satyanarayana, and Punna Rao, 2000; Senthilnathan and Srinivasan 1994).

\begin{tabular}{|c|c|c|c|}
\hline Pineapple Production & & & \\
\hline Variable & Coefficient & Standard Error & $t$-Value \\
\hline Constant & 627315.92 & 241632.75 & 2.59 \\
\hline Caste & 87812.55 & 21615.59 & 4.04 \\
\hline Age & 59312.23 & 19623.44 & -3.02 \\
\hline Education & 86415.27 & 78918.37 & 1.09 \\
\hline Family Size & 59815.65 & 19781.27 & -3.02 \\
\hline Farm Income & 57318.38 & 18723.72 & 3.06 \\
\hline Non-farm Income & 67332.49 & 18742.77 & 3.59 \\
\hline Land Holding & 52436.5 & 39672.0 & 1.32 \\
\hline Fertilizer use level & 87432.5 & 20415 . & 4.28 \\
\hline Pesticide use level & 67813.3 & 21765.6 & 3.11 \\
\hline Mechanization & 97416.7 & 12192.5 & 7.98 \\
\hline$R^{2}$ & 0.9269 & & \\
\hline$F$-ratio & 29.65 & & \\
\hline
\end{tabular}

\section{Problems Faced by the Sample Farmers}

This section deals with farmers' problems in production of pineapple. It can be assessed with the help of 16 factors on a 5-point rating scale (Sivakkolundu, 2021). These include high cost of planting material delay in payments, fluctuation in market price, high cost of borrowing, non-availability of adequate labor, weighment problems, lack of grading facilities, heart rot disease of pineapple, non-availability of credit in time, inadequate electricity for irrigation, non-availability of market information, lack of cold storage facilities, non-availability of fertilizers in time, non-availability of planting materials in time, absence of regulated markets, and lack of technical knowhow. The per quintal marketing cost of producer seller was the highest in Bangalore market followed by Hubli market and Bijapur market (Shivamurthy, 1991).

\begin{tabular}{|l|c|c|c|c|c|c|c|}
\hline Table 12: Problems Faced by the Sample Farmers \\
\hline Variables & Arasampatti & Keeraikadu & Sellipatty & Bellakadu & Thottikadu & Vadagurpatty & Total \\
\hline $\begin{array}{l}\text { Non-availability of planting } \\
\text { materials in time }\end{array}$ & 2.16 & 2.42 & 3.12 & 3.01 & 2.45 & 2.66 & 2.64 \\
\hline $\begin{array}{l}\text { Non-availability of fertilizers } \\
\text { in time }\end{array}$ & 2.2 & 2.32 & 3.26 & 3.29 & 2.45 & 2.61 & 2.69 \\
\hline $\begin{array}{l}\text { Inadequate electricity for } \\
\text { irrigation }\end{array}$ & 2.31 & 2.52 & 3.56 & 3.74 & 2.63 & 2.57 & 2.89 \\
\hline $\begin{array}{l}\text { Non-availability of adequate } \\
\text { labor }\end{array}$ & 3.31 & 3.52 & 3.11 & 3.63 & 3.63 & 2.54 & 3.29 \\
\hline
\end{tabular}




\begin{tabular}{|c|c|c|c|c|c|c|c|}
\hline \multicolumn{8}{|l|}{ Table 12 (Cont.) } \\
\hline Variables & Arasampatti & Keeraikadu & Sellipatty & Bellakadu & Thottikadu & Vadagurpatty & Total \\
\hline Lack of technical know how & 2.19 & 2.52 & 2.26 & 2.59 & 2.63 & 2.81 & 2.50 \\
\hline High cost of planting material & 3.85 & 3.54 & 3.31 & 3.7 & 3.57 & 3.64 & 3.60 \\
\hline Non-availability of credit in time & 3.06 & 3.11 & 2.84 & 2.58 & 3.28 & 3.35 & 3.04 \\
\hline High cost of borrowing & 3.37 & 3.28 & 3.09 & 2.97 & 3.51 & 3.85 & 3.35 \\
\hline Heart rot disease of pineapple & 3.18 & 3.07 & 3.16 & 2.81 & 3.09 & 3.36 & 3.11 \\
\hline Absence of regulated markets & 2.34 & 3.27 & 2.16 & 2.71 & 2.45 & 2.61 & 2.59 \\
\hline Fluctuation in market price & 3.21 & 3.09 & 3.4 & 3.49 & 3.58 & 3.8 & 3.43 \\
\hline Lack of grading facilities & 2.59 & 2.87 & 3.25 & 3.11 & 3.43 & 3.74 & 3.17 \\
\hline Lack of cold storage facilities & 2.17 & 2.6 & 3.02 & 3.11 & 2.46 & 3.12 & 2.75 \\
\hline Delay in payments & 3.37 & 3.62 & 3.22 & 3.81 & 3.7 & 3.49 & 3.54 \\
\hline Weighment problems & 3.09 & 3.13 & 3.27 & 3.18 & 3.59 & 3.06 & 3.22 \\
\hline $\begin{array}{l}\text { Non-availability of market } \\
\text { information }\end{array}$ & 3.02 & 3.29 & 2.89 & 2.69 & 2.59 & 2.46 & 2.82 \\
\hline Average & 2.81 & 2.89 & 3.01 & 3.21 & 3.05 & 3.16 & 3.05 \\
\hline
\end{tabular}

As far as the sample villages are concerned, the Bellakadu Vadagurpatty village was ranked at first in facing the problems on the basis of mean scores and this followed by Thottikadu village, Sellipatty village, Keeraikadu village and Arasampatti village respectively.

The village wise analysis reveals the following facts. Majority of the farmers of Bellakadu (60\%) and Arasampatti village make use of lorry to transport their pineapples. A vast majority of the farmers of Keeraikadu village (58\%) and Thottikadu village $(60 \%)$ make use of tractor to transport their pineapples. The bullock cart usage is quite common among the farmers of Vadagurpatty village.

\begin{tabular}{|c|c|c|c|c|c|}
\hline Villages & Bullock cart & Tempo & Tractor & Lorry & Total \\
\hline Arasampatty & $\begin{array}{c}12 \\
(24.00)\end{array}$ & $\begin{array}{c}8 \\
(16.00)\end{array}$ & $\begin{array}{c}9 \\
(18.00)\end{array}$ & $\begin{array}{c}21 \\
(42.00)\end{array}$ & 50 \\
\hline Keeraikadu & $\begin{array}{c}6 \\
(12.00)\end{array}$ & $\begin{array}{c}8 \\
(16.00)\end{array}$ & $\begin{array}{c}29 \\
(58.00)\end{array}$ & $\begin{array}{c}7 \\
(14.00)\end{array}$ & 50 \\
\hline Sellipatty & $\begin{array}{c}9 \\
(18.00)\end{array}$ & $\begin{array}{c}30 \\
(60.00)\end{array}$ & $\begin{array}{c}6 \\
(12.00)\end{array}$ & $\begin{array}{c}5 \\
(10.00)\end{array}$ & 50 \\
\hline Bellakadu & $\begin{array}{c}7 \\
(14.00)\end{array}$ & $\begin{array}{c}8 \\
(16.00)\end{array}$ & $\begin{array}{c}5 \\
(10.00)\end{array}$ & $\begin{array}{c}30 \\
(60.00)\end{array}$ & 50 \\
\hline Thottikadu & $\begin{array}{c}9 \\
(18.00)\end{array}$ & $\begin{array}{c}5 \\
(10.00)\end{array}$ & $\begin{array}{c}30 \\
(60.00)\end{array}$ & $\begin{array}{c}6 \\
(12.00)\end{array}$ & 50 \\
\hline Vadagurpatty & $\begin{array}{c}29 \\
(58.00)\end{array}$ & $\begin{array}{c}8 \\
(16.00)\end{array}$ & $\begin{array}{c}6 \\
(12.00)\end{array}$ & $\begin{array}{c}7 \\
(14.00)\end{array}$ & 50 \\
\hline Total & $\begin{array}{c}72 \\
(24.00)\end{array}$ & $\begin{array}{c}67 \\
(22.33)\end{array}$ & $\begin{array}{c}85 \\
(28.33)\end{array}$ & $\begin{array}{c}76 \\
(25.33)\end{array}$ & 300 \\
\hline
\end{tabular}

Note: Figures in parentheses denote percentage. 
It is obvious that tractor usage is quite common in marketing pineapples and it occupies the first position followed by lorry, bullock cart and tempo usages.

A study of data in Table 14 indicates the farm wise respondents' views on grading pineapple for marketing purpose. Majority of the marginal farmers (57.14\%) and small farmers $(44.74 \%)$ stated that fleshy nature of pineapple determines the quality of pineapple. The medium farmers (48.89\%) stated that moisture content of pineapple determines the quality of pineapple. A more than half of the large farmers stated that freshness determines the quality of pineapple. These costs are determined by the producer's performance and efficiency of different marketing functionaries which in turn influence the returns to the growers (Shivanand, 2002).

Table 14: Opinion of Respondents on Grading of Pineapples - Farm Wise

\begin{tabular}{|c|c|c|c|c|c|c|c|}
\hline \multirow{3}{*}{ Farm Size } & \multirow{2}{*}{\multicolumn{2}{|c|}{$\begin{array}{c}\text { Quality Wise } \\
\text { Classification of Vegetables }\end{array}$}} & \multicolumn{3}{|c|}{ Factors Determining Quality of Vegetables } & \multirow{3}{*}{ Total } & \multirow{3}{*}{ Grand Total } \\
\hline & & & \multirow{2}{*}{ Freshness } & \multirow[b]{2}{*}{$\begin{array}{l}\text { Moisture } \\
\text { Content }\end{array}$} & \multirow[b]{2}{*}{$\begin{array}{l}\text { Fleshy } \\
\text { Nature }\end{array}$} & & \\
\hline & Yes & No & & & & & \\
\hline Marginal & $\begin{array}{c}63 \\
(57.80)\end{array}$ & $\begin{array}{c}46 \\
(42.20)\end{array}$ & $\begin{array}{c}14 \\
(22.22)\end{array}$ & $\begin{array}{c}13 \\
(20.63)\end{array}$ & $\begin{array}{c}36 \\
(57.14)\end{array}$ & 63 & 109 \\
\hline Small & $\begin{array}{c}76 \\
(89.41)\end{array}$ & $\begin{array}{c}9 \\
(10.59)\end{array}$ & $\begin{array}{c}29 \\
(38.16)\end{array}$ & $\begin{array}{c}13 \\
(17.11)\end{array}$ & $\begin{array}{c}34 \\
(44.74)\end{array}$ & 76 & 85 \\
\hline Medium & $\begin{array}{c}45 \\
(86.54)\end{array}$ & $\begin{array}{c}7 \\
(13.46)\end{array}$ & $\begin{array}{c}14 \\
(31.11)\end{array}$ & $\begin{array}{c}22 \\
(48.89)\end{array}$ & $\begin{array}{c}9 \\
(20.00)\end{array}$ & 45 & 52 \\
\hline Large & $\begin{array}{c}46 \\
(85.19)\end{array}$ & $\begin{array}{c}8 \\
(14.81)\end{array}$ & $\begin{array}{c}27 \\
(58.70)\end{array}$ & $\begin{array}{c}10 \\
(21.74)\end{array}$ & $\begin{array}{c}9 \\
(19.57)\end{array}$ & 46 & 54 \\
\hline Total & $\begin{array}{c}230 \\
(76.67)\end{array}$ & $\begin{array}{c}70 \\
(23.33)\end{array}$ & $\begin{array}{c}84 \\
(36.52)\end{array}$ & $\begin{array}{c}58 \\
(25.22)\end{array}$ & $\begin{array}{c}88 \\
(38.26)\end{array}$ & 230 & 300 \\
\hline
\end{tabular}

Note: Figures in parentheses denote percentage.

Source: computed

It is seen clearly from the above analysis that majority of the farmers are satisfied with the present pricing system. In general, farmers are dissatisfied with preset pricing system owing to lack of coordination among the farmers while fixing the price, lack of price control mechanism among the farmers and low selling price of pineapples.

\begin{tabular}{|c|c|c|c|c|c|c|c|}
\hline \multirow{3}{*}{ Villages } & \multirow{2}{*}{\multicolumn{2}{|c|}{$\begin{array}{c}\text { Satisfaction of } \\
\text { Present Pricing System }\end{array}$}} & \multicolumn{3}{|c|}{ Reasons for Dissatisfaction of Pricing } & \multirow{3}{*}{ Total } & \multirow{3}{*}{ Grand Tota } \\
\hline & & & \multirow{2}{*}{$\begin{array}{c}\text { Low } \\
\text { Price }\end{array}$} & \multirow{2}{*}{$\begin{array}{l}\text { No Discussion } \\
\text { Among Farmers }\end{array}$} & \multirow{2}{*}{$\begin{array}{c}\text { No Price Control } \\
\text { Among Farmers }\end{array}$} & & \\
\hline & Yes & No & & & & & \\
\hline Arasampatty & $\begin{array}{c}18 \\
(36.00)\end{array}$ & $\begin{array}{c}32 \\
(64.00)\end{array}$ & $\begin{array}{c}18 \\
(56.25)\end{array}$ & $\begin{array}{c}8 \\
(25.00)\end{array}$ & $\begin{array}{c}6 \\
(18.75)\end{array}$ & 32 & 50 \\
\hline Keeraikadu & $\begin{array}{c}6 \\
(12.00)\end{array}$ & $\begin{array}{c}44 \\
(88.00)\end{array}$ & $\begin{array}{c}12 \\
(27.27)\end{array}$ & $\begin{array}{c}10 \\
(22.73)\end{array}$ & $\begin{array}{c}22 \\
(50.00)\end{array}$ & 44 & 50 \\
\hline Sellipatty & $\begin{array}{c}11 \\
(22.00)\end{array}$ & $\begin{array}{c}39 \\
(78.00)\end{array}$ & $\begin{array}{c}9 \\
(23.08)\end{array}$ & $\begin{array}{c}8 \\
(20.51)\end{array}$ & $\begin{array}{c}22 \\
(56.41)\end{array}$ & 39 & 50 \\
\hline Bellakadu & $\begin{array}{c}14 \\
(28.00)\end{array}$ & $\begin{array}{c}36 \\
(72.00)\end{array}$ & $\begin{array}{c}8 \\
(22.22)\end{array}$ & $\begin{array}{c}12 \\
(33.33)\end{array}$ & $\begin{array}{c}16 \\
(44.44)\end{array}$ & 36 & 50 \\
\hline Thottikadu & $\begin{array}{c}15 \\
(30.00)\end{array}$ & $\begin{array}{c}35 \\
(70.00)\end{array}$ & $\begin{array}{c}24 \\
(68.57)\end{array}$ & $\begin{array}{c}6 \\
(17.14)\end{array}$ & $\begin{array}{c}5 \\
(14.29)\end{array}$ & 35 & 50 \\
\hline Vadagurpatty & $\begin{array}{c}10 \\
(20.00)\end{array}$ & $\begin{array}{c}40 \\
(80.00)\end{array}$ & $\begin{array}{c}25 \\
(62.50)\end{array}$ & $\begin{array}{c}8 \\
(20.00)\end{array}$ & $\begin{array}{c}7 \\
(17.50)\end{array}$ & 40 & 50 \\
\hline Total & $\begin{array}{c}74 \\
(24.67)\end{array}$ & $\begin{array}{c}226 \\
(75.33)\end{array}$ & $\begin{array}{c}96 \\
(42.48)\end{array}$ & $\begin{array}{c}52 \\
(23.01)\end{array}$ & $\begin{array}{c}78 \\
(34.51)\end{array}$ & 226 & 300 \\
\hline
\end{tabular}




\section{Findings}

- Among different farmers, the marginal farmers are more in number and they contributed $33 \%$ in the total farmers.

- Farmers who fall under the higher income categories are low in number when compared to first two income categories.

- Only a few farmers live in the thatched and tailed houses.

- The total cost of pineapple production is worked out to be Rs. 118837 per acre during first years of cultivation.

- In general small farmers have less cost of pineapple cultivation when compared to large farmers.

- The overall benefit cost ratio of pineapple cultivation is worked out to be 1.38 including inter crop cultivation and 1.18 with pineapple cultivation alone.

- Among the sample villages, the performance of Keeraikadu village is best with respect to economics of pineapple cultivation and it is last in the case of Thottikadu village.

- The moderate problems are identified as weighing problems, lack of grading facilities, heart rot disease of pineapple, and non-availability of credit in time.

- It is concluded that large farmers have high distance of accessing to market place for their pineapples in contrast to marginal farmers.

- It was concluded that large farmers make use of mainly lorry and tractor service to market their pineapples.

- As far as the marketing function is concerned the greatly depends upon the grading.

- In general, it is concluded that medium farmers occupy the first position in rating moisture content quality of pineapple.

- These advantages are realized mainly among the respondents of Sellipatty, Bellakadu and Arasampatti villages.

- It is observed that that majority of the farmers are not satisfied with the present pricing system.

- In general, majority of the large farmers are dissatisfied with preset pricing system due to lack of price control mechanism among the farmers and low selling price of pineapples.

- The findings of respondents' views on marketing problems indicate the following facts.

\section{Results of Hypotheses Testing}

1. There is no significant difference in the prospects of pineapple cultivation among the farmers of different villages in the study area.

2. There is no significant difference in the problems faced by the farmers of different villages in the study area.

3. There is no significant difference in the problems faced by the farmers of different farm sizes in the study area.

4. There is no significant difference in the opinion of the farmers of different villages on the problems of marketing of pineapples.

\section{Suggestions}

- The pineapple production depends upon the quality of inputs given by the farmers. The inputs such as fertilizers, pesticides, seeds are not continuously available to the farmers. Government should come forward to ensure the availability of these inputs in time.

- It is inferred that there is lack technical knowhow to promote the pineapple production in the study area. The department of horticulture and agriculture has to carry out many researches to promote the pineapple production.

- A special board can be set up for pineapple just like tea board, coffee board to promote the pineapple cultivation.

- Periodical training should be given to the farmers on pineapple cultivation. This would help them to improve their cultivation.

\section{Conclusion}

The role of agricultural commodities produced in the hilly area play a crucial role in Indian economy. The present study deeply analysed the economics of pineapple cultivation in the Kollihills of Namakkal district, India. Since the maximum number of farmers are backward and scheduled group, their socio and economic status are still worse. Regarding the cost benefit of the pineapple cultivation, the large farmers benefited much when compared to small farmers. This is 
because of the fact that the large farmers enjoy from the economies of large scale production. The farmers of pineapple cultivation in this study face some sorts of problems which should be overcome. If the above said suggestions are fulfilled, the farmers of pineapple cultivation in this study area get new life in their cultivation.

\section{References}

Begum, A. and Raha, S.K. (2002). Marketing of Banana in Selected areas of Bangladesh. Eco. Affairs Kolkata, 47(3), 158166.

Brij Bala (2006). Marketing System for Apple in Hills Problems and Prospects (A Case Study of Kullu District, Himachal Pradesh. Indian J. Agril. Mkting, 8(5), 285-293.

Chapke, R. (2000). Knowledge and Adoption of Farmers About Bio-control Measures. Maharashtra J. Extn. Edu., 19, 41-47.

Gunjate, R.T. (1997). Cashew Plantation Management: Problems Prospects and Approaches. The Cashew, 11(2), 15-19.

Handiganur, S. (1995). Economics of Production and Processing of Grapes in Bijapur District, Karnataka. M.Sc. (Agri.) Thesis, Univ. Agril. Sci., Dharwad.

Hiremath, (1993). Economics of Production and Marketing of Lime in Bijapur District. Karnataka. M.Sc. (Agri.) Thesis, Univ. Agril. Sci., Dharwad.

More, S.S. (1999). Economics of Production and Marketing of Banana in Maharashtra State. M.Sc. (Agri.) Thesis, Univ. Agril. Sci., Dharwad.

More, M.R., Jadhav, S.N. and Penke, M.S. (2000). Impact of training Krishi Vigyan Kendra and Knowledge and Adoption of Cotton Cultivation Practices. Maharashtra J. Extn. Edu., 19, 200.

Patil, B.N., Suryavanshi, S.D. and Desale, P.G. (1987). Acreage Response of Banana In Jalagaon District of Western Maharashtra. Ind. J. Agric. Econ., 42(3), 458-459.

Patil and Pramod Kumar (1986). Economic Viability of investments in Alphanso Mango Plantations in Ratnagiri District of Maharashtra. Ind. J. Agril. Econ., 2(1), 20-25.

Pawan Dahiya, Singh, I.J. and Rai, K.N. (2002). Cost Benefit Analysis of Ber Cultivation in Rohtak District of Haryana. Ind. J. of Agril. Mkting, 16(2), 49-52.

Rajgopal (1987). Economics of Fruit Production and Marketing of India. A Study of Selected Crops. Ind. J. of Agril. Econ., 42, 465.

Raju, V.T., Dasari, V.S. and Ravishankar, C. (1987). Spatio-Temporal Growth and Distribution of Fruit Crops in Andhra Pradesh. Ind. J. Agric. Econ., 42(4), 438-445.

Rane, A.A. and Bagade, S.R. (2006). Economics of Production and Marketing of Banana in Sindhur District Maharashtra. Ind. J. Agril. Mkting, 20(1), 38-45.

Sathihal, D.G. (1993). Economics of Production and Marketing Of Per in Bijapur District. Karnataka. M.Sc. (Agri.) Thesis, Univ. Agril. Sci., Dharwad.

Satyanarayana, G. and Punna Rao, P. (2000). Knowledge of Oil Palm Growers. J. Extn. Edu., 11(3), 2866-2870.

Senthilnathan, S. and Srinivasan, R. (1994). Production and Marketing of Poovan Banana in Trichirapalli district of Tamil Nadu. Ind. J. of Agril. Mkting, 8(1), 46-53.

Shivamurthy, G.R. (1991). A Study on the Knowledge And Adoption Behaviour Of Arecanut And Cardamom Growers in Shimoga district of Karnataka state. M.Sc. (Agri.) Thesis, Univ. Agric. Sci., Dharwad.

Sivakkolundu. C. (2012). Nutritional Value of Pine Apple. Kisan World, 39 (11), Sakthi Sugars Publication, Chennai.

Sivakkolundu. C. (2013). Nutritional and Medicinal Value of Rose Apple. Kisan World. 40 (4), Sakthi Sugars publications, Chennai.

Sivakkolundu. C. (2016). Kolli Hills the small mountain range of Tamil Nadu. Kisan World, 43 (6), 55-57, Sakthi Sugars Publication, Chennai.

Sivakkolundu. C. (2021). Production of Pineapple. Journal of Contemporary Issues in Business and Government, 27 (2), 5655-5671. 
Shivanand, S.G. (2002). Performance of Banana Plantation in North Karnataka. An Economic Analysis. M.Sc. (Agri.) Thesis, Univ. Agril. Sci., Dharwad.

Cite this article as: C. Sivakkolundu (2021). A Study on Production and Marketing of Pineapple in Kolli Hills, Namakkal District, Tamil Nadu - India. International Journal of Agricultural Sciences and Technology. 1(4), 33-46. doi: 10.51483/IJAGST.1.4.2021.33-46. 